\title{
A Quantitative Approach to Assessing the Technical and Economic Performance of Source Containment Options for Contaminated Aquifers
}

\author{
Alessandro Casasso*(D), Agnese Salomone, Carlo Bianco (D, Giovanni Prassede and Rajandrea Sethi (D) \\ Department of Environment, Land and Infrastructure Engineering (DIATI), Politecnico di Torino, \\ Corso Duca degli Abruzzi 24, 10129 Torino, Italy; agnesesalomone@gmail.com (A.S.); carlo.bianco@polito.it (C.B.); \\ giovanni.prassede@polito.it (G.P.); rajandrea.sethi@polito.it (R.S.) \\ * Correspondence: alessandro.casasso@polito.it; Tel.: +39-3204213886
}

Citation: Casasso, A.; Salomone, A.; Bianco, C.; Prassede, G.; Sethi, R. A Quantitative Approach to Assessing the Technical and Economic

Performance of Source Containment Options for Contaminated Aquifers. Sustainability 2021, 13, 5346.

https://doi.org/10.3390/su13105346

Academic Editors: Dino Musmarra and Marc A. Rosen

Received: 23 March 2021

Accepted: 7 May 2021

Published: 11 May 2021

Publisher's Note: MDPI stays neutral with regard to jurisdictional claims in published maps and institutional affiliations.

Copyright: (c) 2021 by the authors. Licensee MDPI, Basel, Switzerland. This article is an open access article distributed under the terms and conditions of the Creative Commons Attribution (CC BY) license (https:/ / creativecommons.org/licenses/by/ $4.0 /)$.

\begin{abstract}
The containment of contaminant plumes to protect groundwater from pollution is recognized as a frequent need in brownfield redevelopment. Plume containment can be physical, with slurry walls, jet grouting etc., or hydraulic, with wells capturing the subsurface flow that crosses the contaminated front (Pump \& Treat), or a combination of both types. The choice of the most suitable technique is a difficult task, since various aspects must be taken into consideration. In this paper, we present a framework for evaluating barriers in terms of effectiveness and efficiency, along with a simplified approach for the evaluation of capital and operational costs. The contaminant mass discharge escaping from the containment system is a robust indicator of its effectiveness, and can be derived from modelling results. The abstracted water flowrate is a key indicator of the efficiency and sustainability of each option, especially in the long term. The methodology is tested in a simplified case study and in a real one, highlighting the relevance of modelling results in guiding the choice and design of contaminant source containment systems.
\end{abstract}

Keywords: contaminated site; contaminant source; contaminant transport; groundwater; pollution; water resources; slurry wall; Pump \& Treat

\section{Introduction}

The increasing number of contaminated sites poses a serious challenge for the implementation of remediation measures. Three kinds of remedial approaches can be implemented at a contaminated site: active restoration, containment, and monitored natural attenuation [1]. Active restoration approaches comprise different techniques for removing contaminants or degrading them into less harmful substances, and are typically applied for the treatment of the source zone or of highly concentrated plumes. Active restoration can be performed both ex situ, i.e., by extracting the contaminated matrix and treating it on the surface, or in situ, i.e., by treating the environmental component directly in the subsurface. When possible, in situ techniques are preferred, since they make it possible to reduce not only the remediation costs and time, but also the depletion of resources [2]. Relevant examples of in situ remediation techniques include chemical oxidation [3-6], chemical reduction [7-10], adsorption/immobilization/precipitation processes [11-13], enhanced bioremediation [14,15], and electrochemical treatments [16-18].

Pollutant containment instead aims to avoid or reduce the propagation of contaminants towards sensitive targets. It is applied in most contaminated sites as an emergency measure to prevent the spread of pollutants in the short term. However, containment can be converted to a permanent solution when active approaches are not technically or economically feasible. Finally, monitored natural attenuation consists of the careful control of naturally occurring contaminant degradation $[19,20]$. It is usually applied in the case of residual contaminations, after the source has been treated by active approaches, or low 
concentrated plumes, but only if no sensitive receptors are present downstream of the site. The choice of the most suitable case-specific remedial approaches depends on several factors, such as technical feasibility, legislation, requests by control authorities, planned site reuse, and economic constraints. The challenging task of integrating all these criteria has been widely debated in the literature [21-24].

The containment of contamination sources is a key step to preventing the downstream propagation of pollutants in groundwater systems. Two main containment options are available: hydraulic and physical. The first is the most common on contaminated sites due to its rapid implementation, flexibility and scalability. In addition, water wells are not affected by the limits of reachable depth typical of physical barriers $[20,25,26]$. The functioning principle consists of pumping water from wells (or, more rarely, well points, trenches etc.) at a sufficient rate so that all groundwater crossing the contaminated source is captured [26]. As the extracted water generally needs to be treated, the hydraulic containment systems are often referred to as Pump \& Treat (P\&T) systems. P\&T has been the most widely used option for the remediation of contaminated sites since the 1980s [20]. However, it suffers from several shortcomings and disadvantages, which have been extensively addressed in the literature $[20,25,27-33]$. P\&T has very high operational costs that must be incurred for several years, often decades [20,34-37]. These costs are hard to predict, due to tailing and rebound [1,27]. Tailing occurs when the extracted water exceeds the threshold concentrations, even after a long-elapsed pumping time, thus requiring the treatment to be continued. The rebound is an increase of contaminant concentrations after the operations of the P\&T system have ceased, which may require the system to be restarted. Finally, P\&T is largely ineffective in the treatment contaminants with a low solubility, known as Non-Aqueous Phase Liquids (NAPL).

Physical barrier techniques are based on a local reduction of hydraulic conductivity around the contaminated zone. The most widely used technique is the slurry wall, which can be composed of concrete, concrete with bentonite, or soil mixed with bentonite. Sheet piling, grouting, and jet grouting are also used $[26,38]$. The main drawbacks of physical containment are represented by the irreversibility of the alteration of the groundwater flow field and the high installation cost.

The choice between a hydraulic and physical barrier for the containment of contamination is a topic of general concern and, hence, is well-documented in the literature. Several approaches have been proposed to date to guide this choice, but they have all focused on hydraulic aspects only [39-41] or on contaminant transport through the slurry wall [29,42], without considering contaminant mass discharge to the domain.

The work presented in this paper aims to fill this gap by proposing and demonstrating a quantitative approach to source containment evaluation. The rest of the paper is organized as follows. Section 2 presents the methodology to evaluate and compare the performance and costs of physical and hydraulic containment measures. The evaluation framework proposed is intended for the analysis of the numerical modelling results, as it has become the standard in the design of remediation measures; however, a reference to a few wellknown analytical models is also made. Section 3 provides two examples of the application of the approach proposed: an "ideal" site, with a square contaminant source crossed by a uniform groundwater flow, and a real contaminated site. Different P\&T systems and slurry wall configurations are simulated for both cases, and results are compared to derive the performance indicators described in the previous section. Conclusions are reported in Section 4.

\section{Evaluation Framework}

The choice and the design of the source containment method must be performed considering performance, impacts, and costs over a sufficiently long period of time. This process is generally supported by numerical flow and solute transport modelling. As a calibrated and validated model of the site is available, the different source containment options can be sized, designed, and reproduced with the model. The main design pa- 
rameters are, for hydraulic containment, the number, positions, and pumping rates of wells, whereas the physical containment system is described by the boundary shape, the thickness, the hydraulic conductivity, and dewatering pumping rate (if such system is foreseen). The containment options are subsequently evaluated from the points of view of containment performance and of life-cycle costs.

This Section first addresses specific design and modelling aspects of hydraulic (Section 2.1) and physical containment systems (Section 2.2). Subsequently, Section 2.3 presents the metrics proposed for the evaluation of containment performance and efficiency. A quick and simplified assessment method for life-cycle costs is finally explained in Section 2.4. A summary of the methodology for evaluating performance and life-cycle costs is reported below in Figure 1 and Table 1.
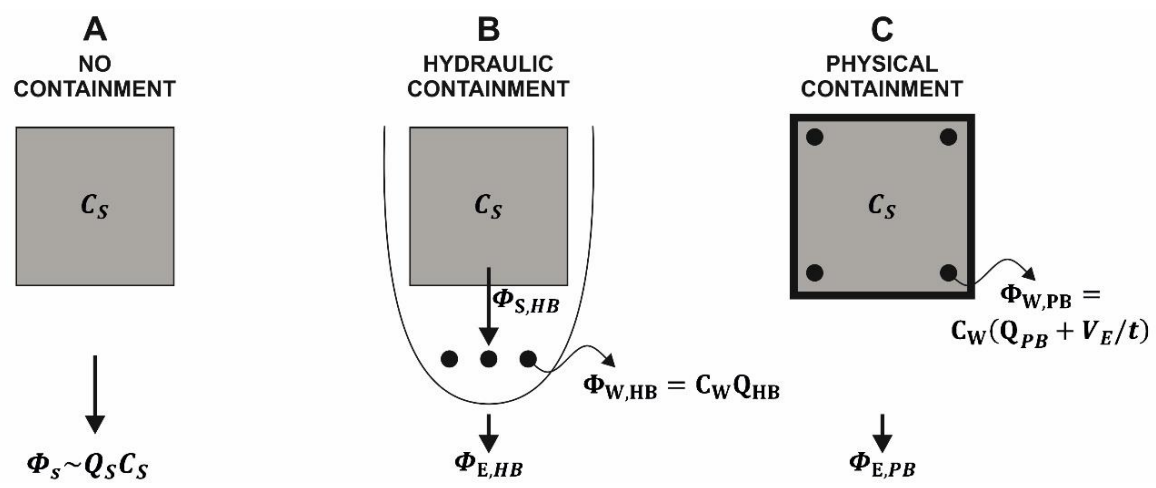

Figure 1. Contaminant mass discharges from a contaminant source with no containment (A), in the presence of a hydraulic containment with a well barrier (B), and in the presence of a physical containment $(\mathbf{C})$.

Table 1. Quantities and parameters considered in the techno-economic evaluation of source containment techniques.

\begin{tabular}{cccc}
\hline Parameter & No Containment & $\begin{array}{c}\text { Hydraulic } \\
\text { Containment }\end{array}$ & Physical Containment \\
\hline Mass discharge from the source $\Phi_{S}$ & $\Phi_{S}$ & $\Phi_{S, H B}$ & Not available \\
Escaped mass discharge $\Phi_{E}$ & $\Phi_{S}$ & $\Phi_{E, H B}$ & $\Phi_{E, P B}$ \\
Abstracted flow rate $Q$ & 0 & $Q_{H B}$ & $Q_{P B}$ \\
Contaminant capture efficiency $\eta_{\Phi}$ & 0 & $\eta_{\Phi, H B}=1-\frac{\Phi_{E, H B}}{\Phi_{S}}$ & $\eta_{\Phi, P B}=1-\frac{\Phi_{E, P B}}{\Phi_{S}}$ \\
Hydraulic efficiency $\eta_{H}$ & 0 & $\eta_{H, H B}=\frac{Q_{S}}{Q_{H B}}$ & $\eta_{H, P B}=\frac{Q_{S}}{Q_{P B}}$ \\
Capital costs CAP & 0 & $u_{W} N d+u_{T P, C A P} Q_{H B}$ & $u_{W} N d+u_{T P, C A P} Q_{P B}+u_{P B} L d+u_{C} \cdot A_{P B}$ \\
Operational costs OP & 0 & $u_{T P, O P} \cdot Q_{H B}$ & $u_{T P, O P} \cdot Q_{P B}$ \\
\hline
\end{tabular}

\subsection{Design and Modelling of Hydraulic Containment Systems}

The sizing and design of hydraulic barriers must ensure that the capture area of the well(s) embraces the whole contaminated area. In the ideal case of a confined aquifer with unlimited extension and homogeneous properties, the maximum amplitude $W_{\max }$ of the capture area is given by the following formula [43]:

$$
W_{\text {max }}=\frac{Q_{H B}}{K b i},
$$

where $b(\mathrm{~m})$ is the saturated thickness, $K\left(\mathrm{~ms}^{-1}\right)$ is the hydraulic conductivity, $i$ (dimensionless) is the hydraulic gradient, and $Q_{H B}\left(\mathrm{~m}^{3} \mathrm{~s}^{-1}\right)$ is the flow rate extracted by the hydraulic barrier. The sizing formula reported in Equation (1) is based on simplifying assumptions that are not met in reality (as shown later in Section 3.2), but it can be used for a quick sizing to be fine-tuned with numerical simulations.

Advective particle tracking packages have been developed for several groundwater modelling software, such as MODFLOW [44] and FEFLOW [45], and have become 
the standard in the design of hydraulic barriers $[26,46]$. The advective particle tracking, however, is not a sufficient tool to verify the correct and effective operation of a P\&T system, as already proved in several research works, among which Ref. [47]. Indeed, hydrodynamic dispersion plays an important role in solute transport and, as shown in Section 3, results in contamination leaks downstream of the P\&T wells, even if the contaminated zone results as completely captured from a hydraulic point of view, as determined by advective particle tracking.

\subsection{Design and Modelling of Physical Containment Systems}

The physical containment of plumes is performed by installing low-permeability barriers, which totally or partially surround the source. Different kinds of barriers are available, the most diffused are slurry walls (soil-bentonite, cement-bentonite, soil-cementbentonite), but sheet pile barriers, geomembrane walls, geo-composite barriers, frozen walls are also used [26]. The design and modelling of physical barriers encompass different aspects, namely, (i) the alteration of groundwater flow field around these installations, (ii) the contaminant leakage from the bounded volume, and (iii) its water budget.

Physical barriers have a major impact on the groundwater flow field and, generally, the alteration consists of a hydraulic head increase upstream of the barrier and a decrease downstream. The alteration of the hydraulic head influences the propagation of contaminants through the slurry wall. Two kinds of mass discharge occur, the diffusive flux $\mathrm{J}_{\mathrm{d}}\left(\mathrm{kg} \cdot \mathrm{s}^{-1} \cdot \mathrm{m}^{-2}\right)$ driven by the concentration gradient, and the advective flux $\mathrm{J}_{\mathrm{a}}\left(\mathrm{kg} \cdot \mathrm{s}^{-1} \cdot \mathrm{m}^{-2}\right)$ driven by the hydraulic head gradient [42], with three possible combinations:

(1) if the hydraulic head is equal at both sides of the wall, the advective flux is null $\left(J_{a}=0\right)$ and contaminants leak only by diffusion (Figure 2A);

(2) if the hydraulic head is higher inside the bounded area compared to the outside, the "positive" advective flux $\mathrm{J}_{\mathrm{a}}$ sums to the diffusive flux $\mathrm{J}_{\mathrm{d}}$, fostering the contaminant leakage from the barrier (Figure 2B);

(3) if the hydraulic head is lower inside the bounded area, the "negative" advective flux $\mathrm{J}_{\mathrm{a}}$ contrasts the diffusive flux $\mathrm{J}_{\mathrm{d}}$ (Figure $2 \mathrm{C}$ ).

The third case is the most favorable for containment, whereas the second is the least favorable and may occur if the slurry walls retain rainfall which has infiltrated the bounded area. Therefore, a capping is often installed to reduce the rainfall infiltration [26] with dewatering wells as an integrative or alternative measure.

The dewatering pumping is performed in two phases, i.e., emptying and maintenance. The emptying is the withdrawal of a volume $V_{E}\left(\mathrm{~m}^{3}\right)$ to achieve the desired negative hydraulic gradient between the internal and the external sides of the slurry wall. The maintenance phase is the withdrawal of a flow rate $Q_{P B}\left(\mathrm{~m}^{3} \cdot \mathrm{s}^{-1}\right)$ that compensates the intake from the top (rainfall infiltration) and from the sides, due to groundwater infiltration from outside the bounded area, which is induced by the dewatering activity itself. The flow rate $Q_{P B}$ can be assigned a priori but, more often, dewatering is activated and switched off depending on upper and lower hydraulic head thresholds, respectively. If the software adopted includes the introduction of such constraints, this modality makes it possible to simulate dewatering in a more realistic way.

Depending on the software adopted, the slurry wall is modelled as a domain portion, i.e., considering its real geometry and assigning specific values of hydraulic conductivity and solute dispersivity. This option has high computational costs due to the need to reproduce the barrier geometry with a very fine grid or mesh. Alternative options have therefore been developed, such as the horizontal flow barrier HFB6 of MODFLOW [48], which reproduces flow and contaminant transport inside a barrier with a 1D geometry. 
A

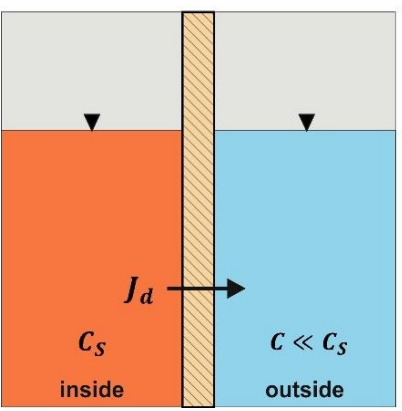

B

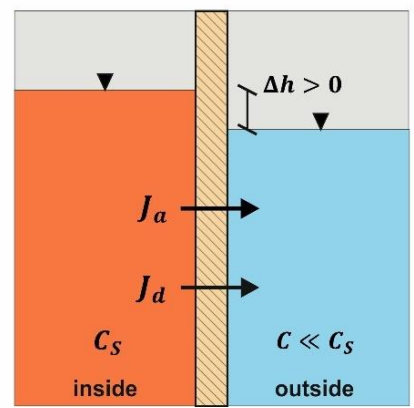

C

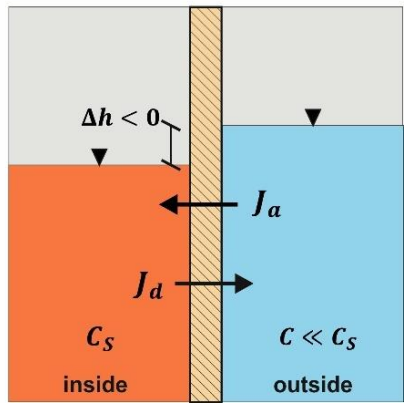

Figure 2. Propagation of a contaminant between the two sides of a physical barrier: (A) purely diffusive transport, in the absence of a hydraulic head gradient; (B) diffusive + advective transport, in the presence of a positive hydraulic head gradient from inside to outside; (C) diffusive transport contrasted by advection, due to a negative hydraulic gradient.

\subsection{Performance and Efficiency Indicators for Source Containment \\ 2.3.1. Performance Indicators}

For a long time, the performance of remediation activities has been based on contaminant concentrations at certain monitoring wells or points of exposition. The recent literature, however, suggests that contaminant mass flux and discharge are often more effective as a performance indicator $[20,30]$. The mass flux $\left(\mathrm{g} \cdot \mathrm{m}^{-2} \cdot \mathrm{d}^{-1}\right)$ is the local intensity of the mass discharge $\Phi\left(\mathrm{g} \cdot \mathrm{d}^{-1}\right)$. As reported in ITRC (2010, [49]), the mass flux provides a clearer information on which parts of the aquifer are conveying the largest amounts of contaminant and, hence, must be prioritized for aquifer remediation. Also, mass discharge and flux data proved effective in assessing the performance of remediation activity and in informing the choice among different techniques [49] and about management of remediation activities [50].

The comparison of source containment methods is another task in which mass discharge and flux can be a more effective indicator than concentrations. Indeed, the resulting spatial distributions of contaminant concentrations in the presence of hydraulic or physical containment can largely differ due to the alteration induced to the groundwater flow field, especially in the presence of complex site geometries and hydrogeological setups.

We propose to focus on the contaminant mass discharge $\Phi_{E}\left(\mathrm{~kg} \cdot \mathrm{s}^{-1}\right)$ that escapes from the (physically or hydraulically) bounded area to evaluate the effectiveness of containment. This quantity can be determined with different mass budget tools included in a groundwater modelling software.

The value of $\Phi_{E}$, however, is not self-explanatory, but should be compared with the contaminant mass discharge that was spreading before the implementation of containment. This mass discharge, defined as $\Phi_{S}\left(\mathrm{~kg} \cdot \mathrm{s}^{-1}\right)$, can be determined with mass budget tools applied to the contaminant source only or, if such a tool is not available, it can be approximated as:

$$
\Phi_{S} \approx Q_{s} \cdot C_{S}
$$

where $Q_{S}\left(\mathrm{~m}^{3} \cdot \mathrm{s}^{-1}\right)$ is the flow rate that crosses the contaminated source and $C_{S}\left(\mathrm{~kg} \cdot \mathrm{m}^{-3}\right)$ is the water-phase concentration of the contaminant at the source. Equation (2) is based on the simplifying assumption of an uniform distribution of $C_{S}$. In addition, it does not consider diffusive and dispersive fluxes, thus underestimating the value of $\Phi_{S}$, as it will be demonstrated in the examples of Section 3.

The leaked contaminant flux in the presence of a physical barrier $\left(\Phi_{E, P B}\right)$ is a straightforward concept and, under due simplification assumptions, it can also be determined with analytical formulae [42]. On the other hand, it is more difficult to understand why a contaminant mass discharge $\left(\Phi_{E, H B}\right)$ leaks from a hydraulic barrier that embraces the whole contamination source with its capture zone. This leakage is due to the hydrodynamic dispersion, which widens the contaminated front and transforms the capture area into 
a secondary contaminant source. The numerical modelling of flow and solute transport make it possible to assess $\Phi_{E, H B}$ with two possible approaches, i.e., with a mass budget tool (if available) applied to the modelling domain or to the portion which is downstream of the well capture zone, and/or through budget closure, calculating the mass discharge $\Phi_{W, H B}$ captured by the wells:

$$
\Phi_{W, H B}=C_{W} Q_{H B},
$$

where $C_{W}\left(\mathrm{~kg} \cdot \mathrm{m}^{-3}\right)$ is the concentration at the well or, in the presence of multiple wells, the flow rate weighted average of concentrations at each well. Based on the flux budget shown in Figure 1, the mass discharge escaping from a hydraulic barrier is:

$$
\Phi_{E, H B}=\Phi_{S, H B}-\Phi_{W, H B} .
$$

The mass discharges of leaked contaminants are the input to derive indicators of the mass discharge removal efficiency $\eta_{\Phi}$ for a hydraulic (HB) and physical (PB) barrier:

$$
\begin{aligned}
& \eta_{\Phi, H B}=1-\frac{\Phi_{E, H B}}{\Phi_{S}}, \\
& \eta_{\Phi, P B}=1-\frac{\Phi_{E, P B}}{\Phi_{S}},
\end{aligned}
$$

Both Equations (5) and (6) refer to the contaminant mass discharge $\Phi_{S}$ occurring in the absence of any containment measure.

\subsubsection{Efficiency Indicators}

Hydraulic barriers are based on groundwater withdrawal and, as shown in Section 2.2, a dewatering pumping can also be introduced inside a source area bounded by a physical barrier to enhance its containment performance. The extracted flow rate (or volume) is a key quantity because pumped water from a contaminated area must be treated. This activity has impacts not only on operational costs, as explained in Section 2.4, but also on the environment due to the energy demand for pumping and treating, the consumption of reagents and sorbents, and the disposal of hazardous waste. Several papers were published on the impacts and life cycle assessment of P\&T systems [51-54], whereas the literature on physical barriers is more limited [55].

At a time $\mathrm{t}$, the volume $V_{H B}\left(\mathrm{~m}^{3}\right)$ extracted by a hydraulic barrier is:

$$
V_{H B}=Q_{H B} t
$$

For a physical barrier with a dewatering system, the abstracted volume $V_{P B}\left(\mathrm{~m}^{3}\right)$ is:

$$
V_{P B}=V_{E}+Q_{P B} t
$$

Ideally, a hydraulic containment system would need to pump at exactly flow rate $Q_{S}$, which crosses the contaminant source. The value of $Q_{S}$ can therefore be used as a reference, deriving the hydraulic efficiency indicator $\eta_{H}$ :

$$
\begin{gathered}
\eta_{H, H B}=\frac{Q_{S}}{Q_{H B}}, \\
\eta_{H, P B}=\frac{Q_{S}}{Q_{P B}+V_{E} / t} .
\end{gathered}
$$

The expected value of hydraulic efficiency for hydraulic barriers is $\eta_{H, H B}<1$. Indeed, some oversizing of the pumped flow rate is needed to deal with the uncertainty of the values of aquifer hydraulic properties and to reduce contaminant leakage downstream of the capture zone. 


\subsection{Economic Assessment}

The choice of a contaminant source containment system must consider installation and operational costs of each option. Generally, hydraulic containment systems have a lower installation cost compared to physical ones, but the operational costs for treating large amounts of contaminated water generally make this choice less convenient in the long term.

The installation costs of a P\&T system can conveniently be divided into two main categories: the well and pumping system and the treatment plant. The former mostly depends on the total depth of the well(s) to be installed, whereas the latter depends on the flow rate that can be treated. The installation cost of water wells and of the pumping system is the sum of fixed (installation of the drilling equipment, well development, pumping system etc.), variable, and depth-dependent costs (drilling activity, well pipe, gravel pack, seal etc.). For sufficiently large and deep boreholes, the variable costs prevail and the cost of well drilling $C A P_{W}(€)$ can be approximated with:

$$
C A P_{W}=u_{W} N d
$$

where $u_{W}(€ / \mathrm{m})$ is the unit cost of drilling, $N$ is the number of wells, and $d(\mathrm{~m})$ is the well average depth. The value of $u_{W}$ can be estimated using unit price lists provided by public authorities or sectorial associations, such as Ref. [56].

The installation cost of slurry walls $C A P_{P B}(€)$ is proportional to the installed surface (i.e., the product of depth and perimeter):

$$
C A P_{P B}=u_{P B} \cdot d \cdot L
$$

where $u_{P B}\left(€ \cdot \mathrm{m}^{-2}\right)$ is the excavation cost per unit surface, which depends on the barrier type (soil-bentonite, cement bentonite) and on the machine used (and, hence, the barrier thickness, the reachable depth etc.); $d(\mathrm{~m})$ and $L(\mathrm{~m})$ are, respectively, the depth and the perimeter of the barrier.

In the case a capping is foreseen, its installation $\operatorname{cost} C A P_{C}(€)$ is proportional to the surface of the area $A_{P B}\left(\mathrm{~m}^{2}\right)$ bounded by the physical barrier:

$$
C A P_{C}=u_{C} \cdot A_{P B}
$$

where $u_{C}\left(€ \cdot \mathrm{m}^{-2}\right)$ is the unit cost of the capping.

Hydraulic barriers require the installation of a treatment plant for the remediation of abstracted water. Physical barriers may require a treatment plant as well if a dewatering well system is installed [26]. The installation cost $C A P_{T P}(€)$ of the treatment plant increases with the flow rate treated, as widely acknowledged in the literature $[34,37,57]$. The following relation is therefore used:

$$
C A P_{T P}=u_{T P, C A P} \cdot Q
$$

where $u_{T P, C A P}\left(€ \cdot \mathrm{m}^{-3} \cdot \mathrm{h}\right)$ is the unit price of the treatment plant and $Q\left(\mathrm{~m}^{3} \mathrm{~h}^{-1}\right)$ is the flow rate treated, i.e., $Q_{H B}$ or $Q_{P B}$ depending on the containment system adopted.

The operational cost of treatment $O P_{T P}(€)$ mostly depends on the water volume withdrawn and, therefore, it is well approximated as:

$$
O P_{T P}=u_{T P, O P} \cdot V
$$

where $u_{T P, O P}\left(€ \cdot \mathrm{m}^{-3}\right)$ is the unit operational cost of water treatment and $V\left(\mathrm{~m}^{3}\right)$ is the total volume abstracted, i.e., $V_{H B}$ or $V_{P B}$ depending on the containment system adopted (see Equations (7) and (8), respectively). The value of the $O P_{T P}$ can also be expressed as an yearly expense (and, hence, in $€ \cdot y^{-1}$ ) if the flow rate abstracted does not undergo appraisable variations through time. Reference values of $u_{T P, C A P}$ and $u_{T P, O P}$ are reported in Table 2 and they exhibit a high variability due to several factors, among which the different 
kinds of contaminants treated, the kind of treatment foreseen, the size of the treatment plant etc. [34,37].

Table 2. Unitary installation and operational costs of P\&T systems $\left(u_{T P, C A P}\right.$ and $\left.t_{T P, O P}\right)$ at major contaminated sites in Italy and USA.

\begin{tabular}{|c|c|c|c|c|}
\hline Authors & Source & Value & $u_{T P, C A P}\left(€ \cdot \mathrm{m}-{ }^{3} \cdot \mathrm{h}\right)$ & $u_{T P, O P}\left(\boldsymbol{\epsilon} \cdot \mathrm{m}^{-3}\right)$ \\
\hline Majone et al. (2009, [37]) & $\begin{array}{l}17 \text { P\&T systems of the National } \\
\text { Interest contaminated Sites } \\
\text { (SIN) of Italy }\end{array}$ & $\begin{array}{l}\text { Median } \\
\text { 25th percentile } \\
\text { 75th percentile }\end{array}$ & $\begin{array}{l}64,634 € \cdot \mathrm{m}^{-3} \cdot \mathrm{h} \\
28,651 € \cdot \mathrm{m}^{-3} \cdot \mathrm{h} \\
87,646 € \cdot \mathrm{m}^{-3} \cdot \mathrm{h}\end{array}$ & $2.71 € \cdot \mathrm{m}^{-3}$ \\
\hline USEPA (2001, [34]) & 32 P\&T systems in the USA & $\begin{array}{l}\text { Median } \\
\text { 25th percentile } \\
\text { 75th percentile }\end{array}$ & $\begin{array}{c}227,748 € \cdot \mathrm{m}^{-3} \cdot \mathrm{h} \\
67,156 € \cdot \mathrm{m}^{-3} \cdot \mathrm{h} \\
1,021,946 € \cdot \mathrm{m}^{-3} \cdot \mathrm{h}\end{array}$ & $\begin{array}{c}4.28 € \cdot \mathrm{m}^{-3} \\
1.56 € \cdot \mathrm{m}^{-3} \\
13.64 € \cdot \mathrm{m}^{-3}\end{array}$ \\
\hline
\end{tabular}

The estimation of installation and operational costs performed with the abovedescribed method is the basis for the economic evaluation of different containment options. Generally, physical containment measures have a higher installation cost, but a lower operational cost compared to hydraulic ones. Therefore, the simple payback time PBT (years) of the physical barrier can be calculated as:

$$
P B T=\frac{C A P_{P B}-C A P_{H B}}{O P_{H B}-O P_{P B}},
$$

where the values of $O P$ are calculated on a yearly base. In the case a dewatering (and water treatment) plant is not installed for the physical barrier option, Equation (16) is simplified by imposing $O P_{P B}=0$.

Finally, there is the possibility that a hydraulic barrier has a higher installation cost than a physical barrier $\left(C A P_{H B}>C A P_{P B}\right)$, in the occurrence of one or more of the following conditions: (i) a highly conductive aquifer, for which it is necessary to withdraw and treat a large flow rate and, hence, to install a high-capacity treatment plant; (ii) the presence of hardly treatable contaminants, for which treatment plants have high unitary costs; and (iii) a site setting (e.g., shallow and thin aquifer and/or a small contamination source) for which the needed size of the physical barrier is small.

\section{Case Studies}

This section presents a few examples of how the methodology described in Section 2 can be applied. An "ideal" case study is described in Section 3.1, along with the modelling setup adopted, and results are discussed in Section 3.2 with the aim of comparing the performance and the applicability of different containment systems. Finally, a case study from a real contaminated site is presented in Section 2.1.

\section{1. "Ideal" Case Study Description and Modelling Setup}

The "ideal" scenario modelled in this work is a square contaminant source $\left(100 \times 100 \mathrm{~m}^{2}\right)$ extending over the entire saturated thickness $(5 \mathrm{~m})$ of the aquifer. The source is modelled as a constant imposed concentration (1st kind transport boundary condition) of $1 \mathrm{mg} / \mathrm{L}$. This assumption is representative of a volume containing a large quantity of pollutant compared to its water solubility. The solute is conservative, i.e., not subject to sorption nor degradation.

A very large rectangular modelling domain around the contaminant source was set $\left(3000 \times 2000 \mathrm{~m}^{2}\right)$ to avoid any boundary effect and to observe the large-scale dispersion of contaminant. The groundwater flow was chosen as aligned with the longest side, with a gradient $\mathrm{i}=6.67 \times 10^{-3}$ assigned by imposing a constant hydraulic head value (1st kind of hydraulic boundary condition) of $30 \mathrm{~m}$ on the upstream domain boundary and $10 \mathrm{~m}$ on the downstream boundary. The hydraulic conductivity of the aquifer was set to $\mathrm{K}=2.5 \times 10^{-4} \mathrm{~ms}^{-1}$ and the effective porosity to $\mathrm{n}_{\mathrm{e}}=0.2$ in the whole domain. 
The dispersivity was set to $\alpha_{\mathrm{L}}=10 \mathrm{~m}$ along the groundwater flow direction and to $\alpha_{\mathrm{T}}=1 \mathrm{~m}$ transversally. These values were imposed considering the scale-dependent relations reported in Ref. [1] and a scale of the transport phenomenon equal to the source size, i.e., $100 \mathrm{~m}$. A molecular diffusion coefficient $\mathrm{D}=10^{-9} \mathrm{~m}^{2} \mathrm{~s}^{-1}$ was set for the solute, which is typical of chloride in aquifers [1].

Two kinds of barriers were considered in different simulations:

(1) A hydraulic barrier composed of one well drilled $150 \mathrm{~m}$ downstream of the border of the contaminant source, and completely screened across the saturated depth.

(2) A physical barrier composed of a slurry wall, crossing the whole aquifer depth, and bounding the whole contaminant source. The barrier has a uniform thickness of $0.8 \mathrm{~m}$ and a hydraulic conductivity $\mathrm{K}_{\mathrm{PB}}=10^{-8} \mathrm{~ms}^{-1}$. The dispersivity was set to $\alpha_{\mathrm{L}}=0.08 \mathrm{~m}$ and $\alpha_{\mathrm{T}}=0.008 \mathrm{~m}$, considering a scale equal to the wall thickness (see Ref. [42]) and the scale-dependent relations reported in Ref. [1].

\subsection{Results and Discussion}

Three kinds of simulations were performed, with a simulation time of 10 years:

(1) A "reference" simulation (REF) to assess the contaminant mass discharge $\Phi_{S, R E F}$ that would occur in the absence of any containment system.

(2) The simulation of hydraulic containment system with different flow rates (HYD 1, 2, $3,4,5$, and 6 ) to assess the impact of this parameter on the mass discharge capture efficiency $\left(\eta_{\Phi}\right)$.

(3) The simulation of the physical containment system (slurry wall) with or without capping and dewatering system (PHY 1, 2, and 3) to assess the effect of different hydraulic head gradient values between the two sides of the barrier on $\eta_{\Phi}$.

The results of the simulations are summarized in Table 3 and are hereby described.

The reference case (REF) provides the reference values of the flow rate crossing the source $\left(Q_{S, R E F}=72 \mathrm{~m}^{3} \mathrm{~d}^{-1}\right)$ and of the contaminant flux leaving the source $\left(\Phi_{S, R E F}=89.26 \mathrm{~g} \cdot \mathrm{d}^{-1}\right)$. As explained in Section 2.3.1, the value of $\Phi_{S, R E F}$ is higher than the one approximated by Equation (2) due to the additional contribution of kinematic dispersion. The spatial distribution of the contaminant concentration after 10 years is shown in Figure 3. Not unexpectedly, the constant release of contaminant in the domain results in an asymptotic trend with a maximum concentration that decreases with the distance from the source.

The hydraulic barrier was first sized using the value of groundwater flow rate crossing the source in reference conditions, i.e., imposing $Q_{H B, H Y D 1}=Q_{S, R E F}=72 \mathrm{~m}^{3} \mathrm{~d}^{-1}$. Based on Equation (1), which approximates the width of the capture front of a well, this configuration should be able to capture the whole source width; however, as shown in Figure 4, this does not occur. Indeed, the pumping well originates a local increase of groundwater velocities in the capture zone that propagates upstream, reaching the contaminant source as well. Consequently, a P\&T system sized with the value of $Q_{S, R E F}$ does not capture the whole source and a noticeable share of the contaminant mass discharge escapes from the containment system: $\Phi_{E, H Y D 1}=27.96 \mathrm{~g} \cdot \mathrm{d}^{-1}$, resulting in a mass discharge removal efficiency of $\eta_{\Phi, H Y D 1}=68.7 \%$. The flow rate was therefore incremented for the other simulations HYD2 (90 $\mathrm{m}^{3} \mathrm{~d}^{-1}$, i.e., $+25 \%$ ), HYD3 (108 $\mathrm{m}^{3} \mathrm{~d}^{-1}$, i.e., $\left.+50 \%\right)$, HYD4 (126 $\mathrm{m}^{3} \mathrm{~d}^{-1}$, i.e., $\left.+75 \%\right)$, HYD5 $\left(144 \mathrm{~m}^{3} \mathrm{~d}^{-1}\right.$, i.e., $\left.+100 \%\right)$, and HYD6 $\left(216 \mathrm{~m}^{3} \mathrm{~d}^{-1}\right.$, i.e., $\left.+200 \%\right)$.

The HYD2 configuration still does not embrace the whole width of the contaminant source but, as shown in Table 3, the mass discharge removal efficiency increases to $\eta_{\Phi, H Y D 2}=80.3 \%$. With the configuration HYD3 $\left(Q_{H B, H Y D 3}=108 \mathrm{~m}^{3} \mathrm{~d}^{-1}\right)$, the whole contaminant source is covered by the capture zone identified with advective particle tracking, as shown in Figure 4A. P\&T systems are generally sized to achieve this result; however, as shown in Figure 4B, the plume still propagates quite far downstream of the source, reaching concentrations in the order of $0.1 \mathrm{C}_{\mathrm{S}}$. This is confirmed by the value of the escaped mass discharge $\left(\Phi_{E, H Y D 3}=10.71 \mathrm{~g} \cdot \mathrm{d}^{-1}\right)$ that is still $12 \%$ of $\Phi_{S, R E F}$ (that is, $\eta_{\Phi, H Y D 3}=88 \%$ ). The efficiency of hydraulic barriers keeps increasing with the flow rate, as shown in Figure 5 
and Table 3, approaching $100 \%$ of $\eta_{\Phi}$ only for flow rates $Q_{H B}$ equal to 2 or 3 times the one that would have been needed according to Equation (1). This result contrasts with the common assumption that a well capture zone embracing the whole contaminated area is enough for a P\&T to be effective, as reported in several references [26,46,58-60]. Including solute transport in P\&T system modelling is therefore of pivotal importance to design an effective containment measure. In the absence of reliable information on the transport properties of the targeted contaminants, a conservative solute can be assumed.

Table 3. Summary of results for the simulations of the "reference" case (REF) and the 6 hydraulic barrier configurations (HYD 1-6).

\begin{tabular}{|c|c|c|c|c|c|c|c|c|}
\hline Quantity & Unit & REF & HYD1 & HYD2 & HYD3 & HYD4 & HYD5 & HYD6 \\
\hline Contaminant mass discharge from source $\left(\Phi_{S}\right)$ & $g \cdot d^{-1}$ & 89.26 & 97.42 & 99.48 & 101.55 & 103.63 & 105.71 & 114.09 \\
\hline Escaped contaminant mass discharge $\left(\Phi_{E}\right)$ & $\mathrm{g} \cdot \mathrm{d}^{-1}$ & 89.26 & 27.96 & 17.61 & 10.71 & 5.44 & 2.28 & 0.74 \\
\hline Abstracted flow rate $\left(Q_{H B}\right.$ or $\left.Q_{P B}\right)$ & $\mathrm{m}^{3} \mathrm{~d}^{-1}$ & 0 & 72 & 90 & 108 & 126 & 144 & 216 \\
\hline Contaminant capture efficiency $\left(\eta_{\Phi}\right)$ & & $0 \%$ & $68.7 \%$ & $80.3 \%$ & $88.0 \%$ & $93.9 \%$ & $97.4 \%$ & $99.2 \%$ \\
\hline Hydraulic efficiency $\left(\eta_{H}\right)$ & & N.A. & $100 \%$ & $80 \%$ & $66.7 \%$ & $57.1 \%$ & $50 \%$ & $33.3 \%$ \\
\hline Capital costs $\left(\mathrm{Co}_{\text {inst }}\right)$ & $\mathrm{k€}$ & N.A. & 205.9 & 254.4 & 302.9 & 351.3 & 399.8 & 593.7 \\
\hline Operational costs $\left(\mathrm{Co}_{\mathrm{op}}\right)$ & $\mathrm{k} € / \mathrm{y}$ & N.A. & 71.2 & 89.0 & 106.8 & 124.6 & 142.4 & 213.7 \\
\hline
\end{tabular}
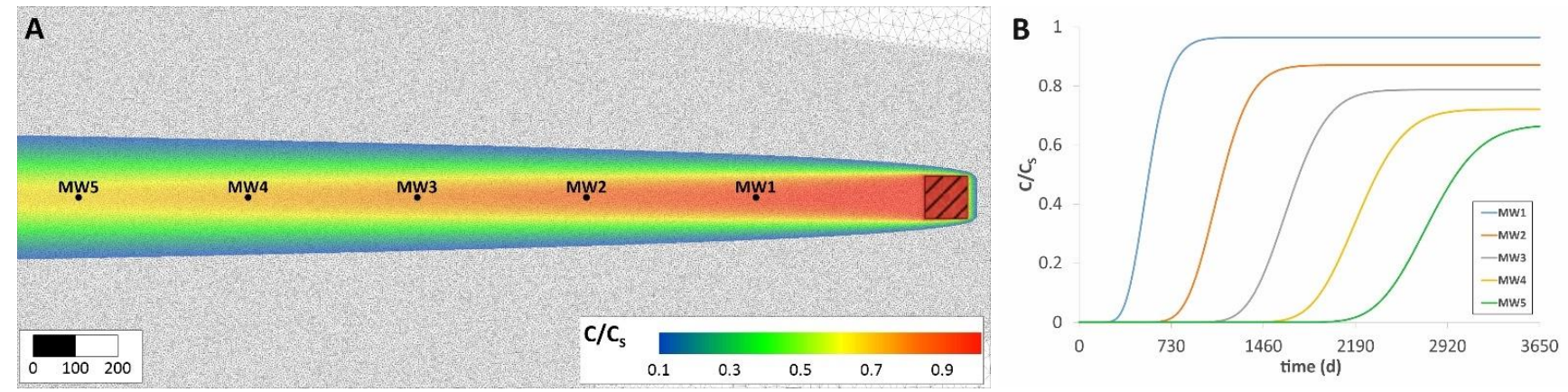

Figure 3. Contaminant concentrations normalized to the source concentration $\left(C / C_{S}\right)$ for the reference case (REF) with no barriers: spatial distribution after 10 years (A) and time trends at the wells MW1-5 located at 250-1700 m downstream of the source $(\mathbf{B})$.
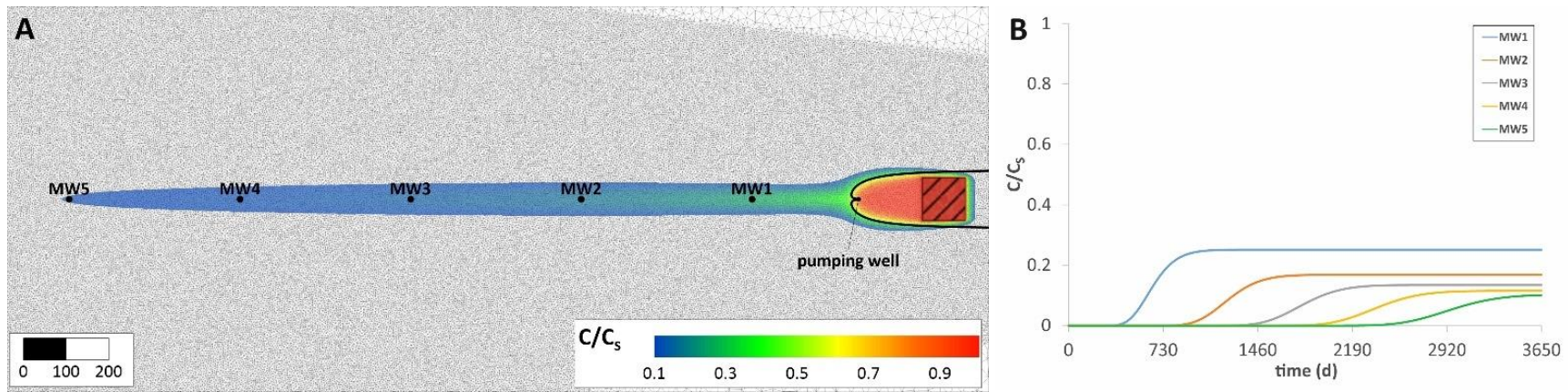

Figure 4. Contaminant concentrations normalized to the source concentration (C/CS) for the hydraulic barrier case HYD3 $\left(Q_{H B}=108 \mathrm{~m}^{3} \mathrm{~d}^{-1}\right)$ : spatial distribution after 10 years $(\mathbf{A})$ and time trends at the wells MW1-5 located 250-1700 m downstream of the source $(\mathbf{B})$. 


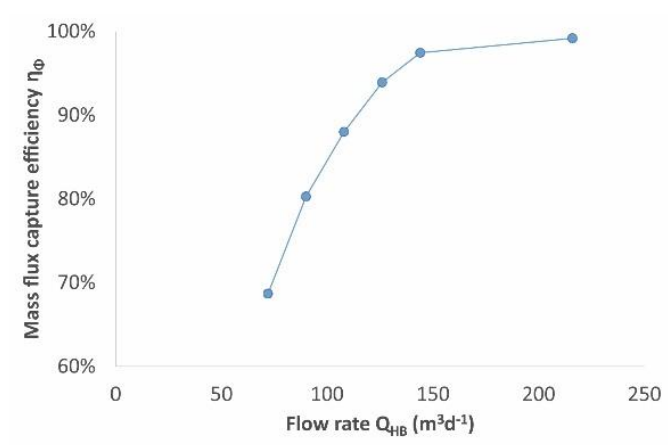

Figure 5. Relation between the flow rate $Q_{H B}$ abstracted by the well and the mass discharge capture efficiency $\eta_{\Phi}$.

Three configurations were simulated for physical barriers (PHY1, 2, and 3):

(1) PHY1: a slurry wall with capping and, hence, without any recharge infiltrating.

(2) PHY2: slurry wall without capping and with a recharge (2nd kind flow) boundary condition of $100 \mathrm{~mm} / \mathrm{y}$.

(3) PHY3: slurry wall with capping and a dewatering well in the center of the basin, set to $Q_{P B} \leq 24 \mathrm{~m}^{3} \mathrm{~d}^{-1}$ with a minimum hydraulic head constraint of $22.5 \mathrm{~m}$ (i.e., about 1.3-2.9 m below the hydraulic head out of the slurry wall).

As shown in Table 4, physical barriers achieve a much higher mass discharge capture efficiency, i.e., $\eta_{\Phi}=96.9-99.9 \%$. When dewatering pumping is foreseen (PHY3), the flow rate $\left(Q_{P B, P H Y 3}=3.57 \mathrm{~m}^{3} \mathrm{~d}^{-1}\right)$ is a small fraction of the ones adopted for hydraulic barriers $\left(72-216 \mathrm{~m}^{3} \mathrm{~d}^{-1}\right)$, as anticipated in Section 2.2. Figure 6 shows the spatial distribution (A) and the time trends (B) of the contaminant concentration for the configuration PHY2, which is the least effective among the studied physical barriers $\left(\eta_{\Phi, P H Y 2}=96.9 \%\right)$.

Table 4. Summary of results for the simulations of the "reference" case (REF) and the 3 physical barrier configurations (PHY 1, 2, and 3). For the case PHY3, the flow rate abstracted is the average value on 10 years of simulation.

\begin{tabular}{|c|c|c|c|c|c|}
\hline Quantity & Unit & REF & PHY1 & PHY2 & PHY3 \\
\hline Contaminant mass discharge from the source $\left(\Phi_{S}\right)$ & $\mathrm{g} \cdot \mathrm{d}^{-1}$ & 89.26 & N.A. & N.A. & N.A. \\
\hline Escaped contaminant mass discharge $\left(\Phi_{E}\right)$ & $g \cdot d^{-1}$ & 89.26 & 0.55 & 2.74 & $<0.01$ \\
\hline Abstracted flow rate $\left(Q_{H B}\right.$ or $\left.Q_{P B}\right)$ & $\mathrm{m}^{3} \mathrm{~d}^{-1}$ & 0 & 0 & 0 & 3.57 \\
\hline Mass discharge capture efficiency $\left(\eta_{\Phi}\right)$ & & $0 \%$ & $99.4 \%$ & $96.9 \%$ & $99.9 \%$ \\
\hline Hydraulic efficiency $\left(\eta_{H}\right)$ & & N.A. & N.A. & N.A. & N.A. \\
\hline Capital costs $\left(\mathrm{Co}_{\text {inst }}\right)$ & $\mathrm{k} €$ & N.A. & 1472.0 & 972.0 & 1525.9 \\
\hline Operational costs $\left(\mathrm{Co}_{\mathrm{op}}\right)$ & $\mathrm{k} € / \mathrm{y}$ & N.A. & 0.0 & 0.0 & 19.8 \\
\hline
\end{tabular}
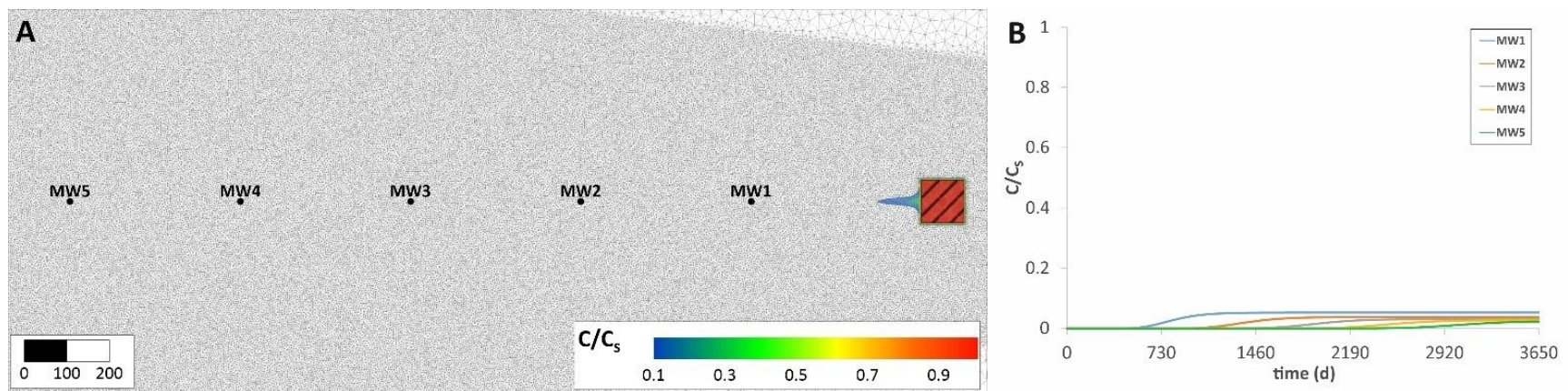

Figure 6. Contaminant concentrations normalized to the source concentration $\left(C / C_{S}\right)$ for the hydraulic barrier case PHY2 (slurry wall, effective infiltration of $100 \mathrm{~mm} / \mathrm{y}$ ): spatial distribution after 10 years (A) and time trends at the monitoring wells MW1-5 located 250-1700 m downstream of the source (B). 
The capital and operational costs were evaluated with the method described in Section 2.4. The following unit cost values were used: $u_{W}=800 € \cdot \mathrm{m}^{-1}$ for the well drilling, $u_{P B}=160 € / \mathrm{m}^{2}$ for the slurry wall, $u_{C}=50 € / \mathrm{m}^{2}$, based on a market survey on Italian case studies, and $u_{T P, \text { inst }}=64,634 € \cdot\left(\mathrm{m}^{3} \cdot \mathrm{h}^{-1}\right)^{-1}, u_{T P, o p}=2.71 € \cdot \mathrm{m}^{-3}$, based on values reported in Table 2 for the Italian SIN (Sites of National Interest) contaminated sites [37].

As shown in Table 3, the hydraulic barrier solutions present a reduction in installation costs by over $80 \%$ compared to the physical barrier with dewatering system (PHY3), which proved to be the optimal solution. However, these lower installation costs are compensated by higher operational costs. Simple payback times of physical barrier solutions (PHY 1, 2, and 3) were calculated against the six hydraulic barrier solutions (HYD 1, 2, 3, 4, 5, and 6) using Equation (16). As shown in Table 5, payback time values range between 1.8 and 25.7 years. Such a wide range of variation is due to the fact that, as explained in Section 2.4 and shown in Table 2, both the installation and the operational costs of P\&T systems depend on the flow rate, which ranges from $Q_{H B, H Y D 1}=72 \mathrm{~m}^{3} \mathrm{~d}^{-1}$ to $Q_{H B, H Y D 6}=$ $216 \mathrm{~m}^{3} \mathrm{~d}^{-1}$ for the six options hypothesized.

The payback time of a physical barrier finds a good term of comparison in the typical lifetime of P\&T systems, which is often in the order of a few decades. For instance, P\&T systems installed in several major Italian contaminated sites have been operating since the early 2000s [25]. Guo et al. (2019, [61]) predicted at least 36 years of future operation for a P\&T system installed at a contaminated site in Tucson (USA) to reach the maximum concentration levels of trichloroethylene permitted by the law. Several of the P\&T systems listed by USEPA (2001, [35]) had been in operation since the 1980s and a few of them are still active.

Table 5. Payback times (years) of adopting physical barrier solutions (PHY1, 2, and 3) and hydraulic barriers (HYD 1, 2, 3, 4, 5 and 6).

\begin{tabular}{cccc}
\hline & PHY1 & PHY2 & PHY3 \\
\hline HYD1 & 17.8 & 10.8 & 25.7 \\
HYD2 & 13.7 & 8.1 & 18.4 \\
HYD3 & 10.9 & 6.3 & 14.1 \\
HYD4 & 9.0 & 5.0 & 11.2 \\
HYD5 & 7.5 & 4.0 & 9.2 \\
HYD6 & 4.1 & 1.8 & 4.8 \\
\hline
\end{tabular}

With the scenarios described above, physical barriers were superior in terms of source containment but had higher installation costs compared to hydraulic barriers. However, the hydraulic properties of the aquifer have a strong effect on the outcome of this evaluation. Four additional scenarios were considered with a higher $\left(\mathrm{K}=10^{-3} \mathrm{~ms}^{-1}\right)$ and a lower $\left(\mathrm{K}=10^{-4} \mathrm{~ms}^{-1}\right.$ ) hydraulic conductivity and the results are shown in Table 6. Two cases were selected for the comparison, i.e., the hydraulic barrier HYD3 (pumping at a rate $50 \%$ higher than $Q_{S, R E F}$ ), and the physical barrier PHY1 (with capping but without dewatering). Results show that the values of mass discharge capture efficiency $\eta_{\Phi}$ are almost independent from the hydraulic conductivity of the aquifer, both for hydraulic barriers (HYD3_high and HYD3_low) and slurry walls (PHY1_high and PHY1_low). On the other hand, the economic analysis leads to a dramatically different conclusion depending on the aquifer hydraulic conductivity. For the lowest value of $K$, the installation cost of a physical barrier is 11.5 times higher and the operational cost of the hydraulic barrier is so low that it takes 31.4 years to recover the investment needed for a slurry wall. By contrast, for the highly conductive aquifer, where a high flow rate must be abstracted and treated, the installation of a hydraulic barrier is only $20 \%$ cheaper than a physical barrier and the payback time of a slurry wall is less than 1 year. 
Table 6. Summary of results for the simulations performed with different hydraulic conductivities of the aquifer: the hydraulic barrier sized with $150 \%$ of $Q_{S}$ in reference conditions (HYD3) and the physical barrier with capping (PHY1) with aquifer hydraulic conductivity values of $\mathrm{K}=10^{-4} \mathrm{~ms}^{-1}$ and $\mathrm{K}=10^{-3} \mathrm{~ms}^{-1}$ (respectively: HYD3_low and HYD3_high, PHY1_low and PHY1_high).

\begin{tabular}{|c|c|c|c|c|c|c|c|}
\hline \multirow{2}{*}{ Quantity } & \multirow[b]{2}{*}{ Unit } & \multicolumn{3}{|c|}{ Low $\mathrm{K}\left(10^{-4} \mathrm{~ms}^{-1}\right)$} & \multicolumn{3}{|c|}{ High K $\left(10^{-3} \mathrm{~ms}^{-1}\right)$} \\
\hline & & REF & HYD3 & PHY1 & REF & HYD3 & PHY1 \\
\hline Contaminant mass discharge from the source $\left(\Phi_{S}\right)$ & $g \cdot d^{-1}$ & 35.82 & 41.46 & N.A. & 357.05 & 406.72 & N.A. \\
\hline Escaped contaminant mass discharge $\left(\Phi_{E}\right)$ & $\mathrm{g} \cdot \mathrm{d}^{-1}$ & 35.82 & 4.81 & 0.54 & 357.05 & 44.70 & 0.56 \\
\hline Abstracted flow rate $\left(Q_{H B}\right.$ or $\left.Q_{P B}\right)$ & $\mathrm{m}^{3} \mathrm{~d}^{-1}$ & 0 & 43.2 & N.A. & 0 & 432 & 0 \\
\hline Contaminant capture efficiency $\left(\eta_{\Phi}\right)$ & & $0 \%$ & $86.6 \%$ & $98.5 \%$ & $0 \%$ & $87.9 \%$ & $99.8 \%$ \\
\hline Hydraulic efficiency $\left(\eta_{H}\right)$ & & N.A. & $66.7 \%$ & N.A. & N.A. & $66.7 \%$ & N.A. \\
\hline Capital costs $\left(\mathrm{Co}_{\text {inst }}\right)$ & $€$ & N.A. & 128.3 & 1472.0 & N.A. & 1175.4 & 1472.0 \\
\hline Operational costs $\left(\mathrm{Co}_{\mathrm{op}}\right)$ & $€ / y$ & N.A. & 42.7 & 0.0 & N.A. & 427.3 & 0.0 \\
\hline
\end{tabular}

\subsection{Application to a Real Case Study}

The proposed approach was applied to a former industrial Italian site-contaminated by chlorinated aliphatic hydrocarbons $(\mathrm{CAH}$ ) - that lies on alluvial deposits hosting an unconfined aquifer with a bottom at $30 \mathrm{~m}$ below ground surface, a saturated thickness of about $16 \mathrm{~m}$ and a hydraulic gradient $\mathrm{i} 3 \times 10^{-2}$. Based on pumping tests, slug tests, and steadystate calibration of a groundwater flow model, the hydraulic conductivity was found to have a moderate spatial heterogeneity with values ranging between $3 \times 10^{-5} \mathrm{~ms}^{-1}$ and $8.4 \times 10^{-5} \mathrm{~ms}^{-1}$. A target contaminated area extending on $17,165 \mathrm{~m}^{2}$ was identified with an average $\mathrm{CAH}$ concentration of $90 \mu \mathrm{g} / \mathrm{L}$. This concentration was assigned as a constant and homogeneous value (1st kind transport boundary condition) and two containment options were evaluated, namely, a P\&T system composed of two wells located at about $55 \mathrm{~m}$ from the downstream border and a slurry wall $\left(0.8 \mathrm{~m}\right.$ thick, $\left.\mathrm{K}=10^{-8} \mathrm{~ms}^{-1}\right)$ surrounding the whole contaminated area (perimeter: $600 \mathrm{~m}$ ).

The reference simulation (case REF) was run in the absence of containment system to assess the reference source contaminant mass discharge $\left(\Phi_{S}=36.47 \mathrm{mg} \cdot \mathrm{d}^{-1}\right)$. A P\&T configuration with a flow rate $Q_{H B}=460 \mathrm{~m}^{3} \mathrm{~d}^{-1}$ was simulated (case HYDa). Based on particle tracking, this is the minimum value of $Q_{H B}$ to capture the whole contaminated area. However, as shown in Table 7, an appraisable share of the contaminant mass discharge still escapes, and the capture efficiency is of $90.3 \%$. The contaminant capture efficiency increases to $98.2 \%$ as the flow rate is increased of $25 \%\left(575 \mathrm{~m}^{3} \mathrm{~d}^{-1}\right.$, case $\left.\mathrm{HYDb}\right)$. This performance is comparable to that of a physical barrier without internal dewatering system (case PHYa with $\eta_{\Phi}=97.5 \%$, see Table 7). In this case, the hydraulic head at the internal side of the slurry wall exceeds the external one up to about $4 \mathrm{~m}$ in the downstream side, thus leaving an appraisable escaped contaminant mass discharge $\left(\Phi_{E}=0.91 \mathrm{mg} \cdot \mathrm{d}^{-1}\right)$. The spatial distribution of CAH concentrations resulting for the configurations HYDb and PHYa are shown in Figure 7A,B, respectively.

A dewatering system that reduces the internal hydraulic head was included (simulation $\mathrm{PHYb}$ ), thus introducing a minimum difference of $1 \mathrm{~m}$ between the external and internal side. In this way, the mass discharge capture efficiency is approximately $100 \%$.

The capital and operational costs of different options were calculated with the methodology described in Section 2.4 and with the same unit costs reported in the previous paragraph, except for the capital cost of the treatment plant $u_{T P, i n s t}=35,000 € \cdot\left(\mathrm{m}^{3} \cdot \mathrm{h}^{-1}\right)^{-1}$ and of the plant operation $u_{T P, o p}=0.70 € \cdot \mathrm{m}^{-3}$. Based on these figures, the payback of the physical barrier solutions (PHYa and PHYb) is about 19-20 years compared to the hydraulic barrier HYDb. In this case, the installation of a hydraulic barrier can be advisable. 


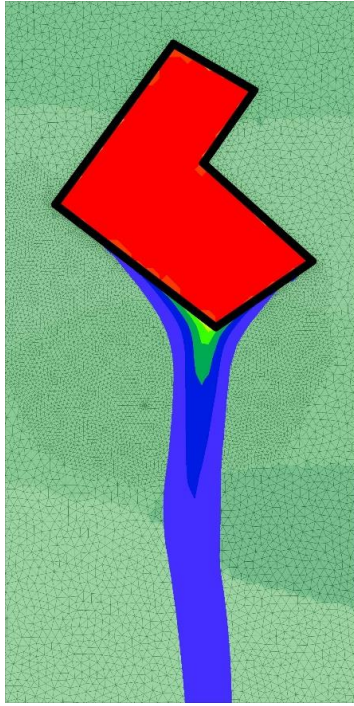

(A)

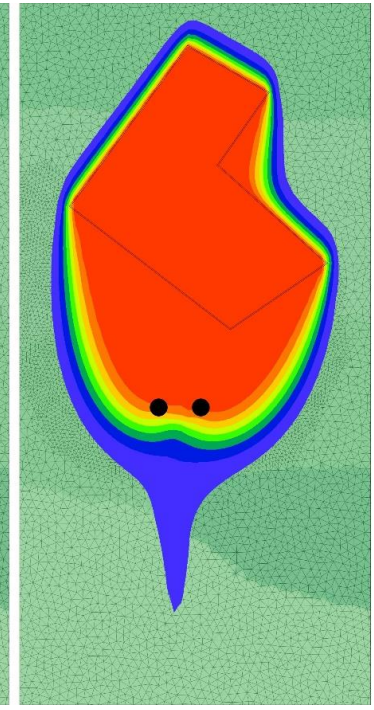

(B)

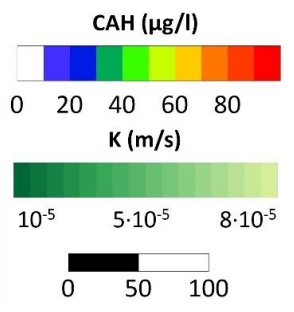

Figure 7. Real case study: spatial distribution of CAH concentrations for the physical barrier configuration PHYa (A) and for the hydraulic barrier configuration HYDb $\left(Q_{H B}=575 \mathrm{~m}^{3} \mathrm{~d}^{-1}\right)(\mathbf{B})$, along with the spatial distribution of hydraulic conductivity.

Table 7. Summary of results for the simulations performed for the real case study.

\begin{tabular}{|c|c|c|c|c|c|c|}
\hline Quantity & Unit & REF & HYDa & HYDb & PHYa & PHYb \\
\hline Contaminant mass discharge from the source $\left(\Phi_{S}\right)$ & $\mathrm{mg} \cdot \mathrm{d}^{-1}$ & 36.47 & 42.27 & 43.65 & N.A. & N.A. \\
\hline Escaped contaminant mass discharge $\left(\Phi_{E}\right)$ & $\mathrm{mg} \cdot \mathrm{d}^{-1}$ & 36.47 & 3.52 & 0.67 & 0.91 & 0.00 \\
\hline Abstracted flow rate $\left(Q_{H B}\right.$ or $\left.Q_{P B}\right)$ & $\mathrm{m}^{3} \mathrm{~d}^{-1}$ & 0 & 460 & 500 & 575 & 0 \\
\hline Contaminant capture efficiency $\left(\eta_{\Phi}\right)$ & & $0.0 \%$ & $90.3 \%$ & $98.2 \%$ & $97.5 \%$ & $100.0 \%$ \\
\hline Hydraulic efficiency $\left(\eta_{H}\right)$ & & N.A. & $99.0 \%$ & $79.2 \%$ & N.A. & N.A. \\
\hline Capital costs $\left(\mathrm{Co}_{\text {inst }}\right)$ & $€$ & N.A. & 718.8 & 777.2 & 3738 & 3784 \\
\hline Operational costs $\left(\mathrm{Co}_{\mathrm{op}}\right)$ & $€ / y$ & N.A. & 117.5 & 127.8 & 146.9 & 0.0 \\
\hline
\end{tabular}

\section{Conclusions}

The containment of contaminations is a relevant management issue for polluted sites. Two options are available: hydraulic barriers, capturing the groundwater flow and the contaminant flux from upstream, and physical barriers, reducing the hydraulic conductivity of the underground around the source. Numerical modelling has become the standard for supporting the choice and the design of containment systems; however, correct modelling assumptions are necessary, along with a robust approach for the interpretation of the results.

We presented a method for the quantitative evaluation of the effectiveness and efficiency of both hydraulic and physical barriers for the containment of contaminant sources. We proposed to assess such efficiency in comparison with the "reference" scenario, i.e., how the plume would spread in the absence of any containment. The term of comparison is the mass discharge of contaminant released by the source in reference conditions $\left(\Phi_{\mathrm{S}}\right)$ and the effectiveness of containment is expressed by the share $\left(\eta_{\Phi}\right)$ of such flux, which is captured by the containment system and, hence, is impeded to reach sensitive targets.

A few simple case studies were simulated to demonstrate the application of the evaluation approach proposed. Results show that the modelling of hydraulic barriers must include solute transport and that flow-only simulation may severely mislead design choices. Indeed, embracing the whole source with the advective capture area of the wells does not guarantee that the whole source contaminant flux will be captured as well. Regarding physical barriers, slurry walls with common characteristics proved very effective in the containment of contaminants. However, attention should be paid on the hydraulic gradient between the two sides of the barrier. 
The approach presented in this paper represents a basis for future works on the development of containment options, comparing their performance with simple and robust indicators.

Author Contributions: Conceptualization, A.C., A.S., G.P., C.B., R.S.; methodology, A.C., C.B., R.S.; software, A.C., A.S., G.P., C.B. writing-original draft preparation, A.C., A.S.; writing-review and editing, A.C., A.S., G.P., C.B., R.S.; supervision, R.S.; funding acquisition, A.C., R.S. All authors have read and agreed to the published version of the manuscript.

Funding: This research received no external funding.

Institutional Review Board Statement: Not applicable.

Informed Consent Statement: Not applicable.

Data Availability Statement: Not applicable.

Acknowledgments: The authors gratefully acknowledge the valuable contribution of Sofia Credaro, who assisted in the proofreading and language editing of the manuscript.

Conflicts of Interest: The authors declare no conflict of interest.

\section{Glossary}

\begin{tabular}{|c|c|}
\hline \multicolumn{2}{|c|}{ Acronyms } \\
\hline NAPL & Non-Aqueous Phase Liquids \\
\hline P\&T & Pump \& Treat \\
\hline \multicolumn{2}{|c|}{ Latin letters } \\
\hline$b$ & Saturated thickness of the aquifer (m) \\
\hline$A_{P B}$ & Area bounded by a physical barrier $\left(\mathrm{m}^{2}\right)$ \\
\hline$C_{S}$ & Contaminant fluid-phase concentration at the source $\left(\mathrm{kg} \cdot \mathrm{m}^{-3}\right)$ \\
\hline$C_{W}$ & Contaminant fluid-phase concentration at the wells $\left(\mathrm{kg} \cdot \mathrm{m}^{-3}\right)$ \\
\hline$C A P_{C}$ & Installation cost of a capping $(€)$ \\
\hline$C A P_{H B}$ & Installation cost of a hydraulic barrier $\left(€ \cdot y^{-1}\right)$ \\
\hline$C A P_{P B}$ & Installation cost of a physical barrier $(€)$ \\
\hline$C A P_{T P}$ & Installation cost of a treatment plant $(€)$ \\
\hline$C A P_{W}$ & Installation cost of wells $(€)$ \\
\hline$d$ & Depth of a well or a physical barrier (m) \\
\hline$i$ & Hydraulic gradient of the aquifer (dimensionless) \\
\hline$J_{a}$ & Contaminant advective flux through a barrier $\left(\mathrm{kg} \cdot \mathrm{s}^{-1} \cdot \mathrm{m}^{-2}\right)$ \\
\hline$J_{d}$ & Contaminant diffusive flux through a barrier $\left(\mathrm{kg} \cdot \mathrm{s}^{-1} \cdot \mathrm{m}^{-2}\right)$ \\
\hline$K$ & Hydraulic conductivity of the aquifer $\left(\mathrm{ms}^{-1}\right)$ \\
\hline$L$ & Perimeter bounded by a physical barrier (m) \\
\hline$N$ & Number of wells (dimensionless) \\
\hline$O P_{H B}$ & Operational cost of a hydraulic barrier $\left(€\right.$ or $\left.€ \cdot y^{-1}\right)$ \\
\hline$O P_{P B}$ & Operational cost of dewatering inside a physical barrier $\left(€\right.$ or $\left.€ \cdot y^{-1}\right)$ \\
\hline PBT & Payback time $(y)$ \\
\hline$Q$ & Flow rate $\left(\mathrm{m}^{3} \mathrm{~s}^{-1}\right)$ \\
\hline$Q_{H B}$ & Flow rate abstracted by the wells of a hydraulic barrier $\left(\mathrm{m}^{3} \mathrm{~s}^{-1}\right)$ \\
\hline$Q_{P B}$ & Flow rate abstracted by dewatering wells at a physical barrier $\left(\mathrm{m}^{3} \mathrm{~s}^{-1}\right)$ \\
\hline$Q_{S}$ & Flow rate crossing the contaminant source $\left(\mathrm{m}^{3} \mathrm{~s}^{-1}\right)$ \\
\hline$u_{W}$ & Unit drilling and installation cost of a well $\left(€ \mathrm{~m}^{-1}\right)$ \\
\hline$u_{P B}$ & Unit excavation and installation cost of a physical barrier $\left(€ \mathrm{~m}^{-2}\right)$ \\
\hline$u_{T P, C A P}$ & Unit installation cost of a treatment plant $\left(€ \mathrm{~m}^{-3} \mathrm{~h}\right)$ \\
\hline$u_{T P, O P}$ & Unit operational cost of a treatment plant $\left(€ \mathrm{~m}^{-3}\right)$ \\
\hline$V_{E}$ & Volume withdrawn in the emptying of a physical barrier $\left(\mathrm{m}^{3}\right)$ \\
\hline$V_{H B}$ & Volume withdrawn by a hydraulic barrier $\left(\mathrm{m}^{3}\right)$ \\
\hline$V_{P B}$ & Volume withdrawn by dewatering well(s) inside a physical barrier $\left(\mathrm{m}^{3}\right)$ \\
\hline$W_{\max }$ & Maximum width of the capture zone $(\mathrm{m})$ \\
\hline
\end{tabular}




$\begin{array}{ll}\text { Greek letters } & \\ \eta_{\Phi, H B} & \text { Contaminant capture efficiency with a hydraulic barrier }\left(\mathrm{kg} \cdot \mathrm{s}^{-1}\right) \\ \eta_{\Phi, P B} & \text { Contaminant capture efficiency with a physical barrier }\left(\mathrm{kg} \cdot \mathrm{s}^{-1}\right) \\ \eta_{H, H B} & \text { Hydraulic efficiency indicator of a hydraulic barrier }\left(\mathrm{kg} \cdot \mathrm{s}^{-1}\right) \\ \eta_{H, P B} & \text { Hydraulic efficiency indicator of a physical barrier }\left(\mathrm{kg} \cdot \mathrm{s}^{-1}\right) \\ \Phi_{E, H B} & \text { Mass discharge escaped from a hydraulic barrier }\left(\mathrm{kg} \cdot \mathrm{s}^{-1}\right) \\ \Phi_{E, P B} & \text { Mass discharge escaped from a physical barrier }\left(\mathrm{kg} \cdot \mathrm{s}^{-1}\right) \\ \Phi_{S} & \text { Mass discharge from the source }\left(\mathrm{kg} \cdot \mathrm{s}^{-1}\right) \\ \Phi_{S, H B} & \text { Mass discharge in the presence of a hydraulic barrier }\left(\mathrm{kg} \cdot \mathrm{s}^{-1}\right) \\ \Phi_{W, H B} & \text { Mass discharge captured by the wells of a hydraulic barrier }\left(\mathrm{kg} \cdot \mathrm{s}^{-1}\right) \\ \Phi_{W, P B} & \text { Mass discharge captured by wells inside a physical barrier }\left(\mathrm{kg} \cdot \mathrm{s}^{-1}\right)\end{array}$

\section{References}

1. Sethi, R.; Di Molfetta, A. Groundwater Engineering A Technical Approach to Hydrogeology, Contaminant Transport and Groundwater Remediation; Springer International Publishing: Cham, Switzerland, 2019; ISBN 978-3-030-20516-4.

2. Zhang, S.; Mao, G.; Crittenden, J.; Liu, X.; Du, H. Groundwater Remediation from the Past to the Future: A Bibliometric Analysis. Water Res. 2017, 119, 114-125. [CrossRef] [PubMed]

3. Yang, Z.-H.; Sheu, Y.-T.; Dong, C.-D.; Chen, C.-W.; Chen, S.; Kao, C.-M. Remediation of Phenol-Contaminated Groundwater Using in Situ Fenton and Persulfate Oxidation: Performance and Mechanism Studies. DWT 2020, 175, 359-368. [CrossRef]

4. Tsitonaki, A.; Petri, B.; Crimi, M.; Mosbæk, H.; Siegrist, R.L.; Bjerg, P.L. In Situ Chemical Oxidation of Contaminated Soil and Groundwater Using Persulfate: A Review. Crit. Rev. Environ. Sci. Technol. 2010, 40, 55-91. [CrossRef]

5. Baciocchi, R.; D'Aprile, L.; Innocenti, I.; Massetti, F.; Verginelli, I. Development of Technical Guidelines for the Application of In-Situ Chemical Oxidation to Groundwater Remediation. J. Clean. Prod. 2014, 77, 47-55. [CrossRef]

6. Pac, T.J.; Baldock, J.; Brodie, B.; Byrd, J.; Gil, B.; Morris, K.A.; Nelson, D.; Parikh, J.; Santos, P.; Singer, M.; et al. In Situ Chemical Oxidation: Lessons Learned at Multiple Sites. Remediation 2019, 29, 75-91. [CrossRef]

7. Mondino, F.; Piscitello, A.; Bianco, C.; Gallo, A.; de Folly D'Auris, A.; Tosco, T.; Tagliabue, M.; Sethi, R. Injection of Zerovalent Iron Gels for Aquifer Nanoremediation: Lab Experiments and Modeling. Water 2020, 12, 826. [CrossRef]

8. Xu, J.; Wang, Y.; Weng, C.; Bai, W.; Jiao, Y.; Kaegi, R.; Lowry, G.V. Reactivity, Selectivity, and Long-Term Performance of Sulfidized Nanoscale Zerovalent Iron with Different Properties. Environ. Sci. Technol. 2019, 53, 5936-5945. [CrossRef] [PubMed]

9. Tosco, T.; Petrangeli Papini, M.; Cruz Viggi, C.; Sethi, R. Nanoscale Zerovalent Iron Particles for Groundwater Remediation: A Review. J. Clean. Prod. 2014, 77, 10-21. [CrossRef]

10. Arato, A.; Fiore, S.; Ruffino, B.; Godio, A.; Zanetti, M.C.; Roati, C. Monitoring of Injection of Hydrogen Release Compounds in a Contaminated Site. In Proceedings of the Near Surface Geoscience 2015-21st European Meeting of Environmental and Engineering Geophysics, Turin, Italy, 6 September 2015.

11. Mohammadian, S.; Krok, B.; Fritzsche, A.; Bianco, C.; Tosco, T.; Cagigal, E.; Mata, B.; Gonzalez, V.; Diez-Ortiz, M.; Ramos, V.; et al. Field-Scale Demonstration of in Situ Immobilization of Heavy Metals by Injecting Iron Oxide Nanoparticle Adsorption Barriers in Groundwater. J. Contam. Hydrol. 2021, 237. [CrossRef]

12. Sbaffoni, S.; Boni, M.R.; Tedesco, P.; Vaccari, M. Fe (II) and Mn (II) Removal from Contaminated Groundwater by Adsorption: A Comparison of Activated Carbon and Pine Bark. Environ. Eng. Manag. J. 2018, 17, 1989-1999. [CrossRef]

13. Falciglia, P.P.; Gagliano, E.; Brancato, V.; Finocchiaro, G.; Catalfo, A.; De Guidi, G.; Romano, S.; Roccaro, P.; Vagliasindi, F.G.A. Field Technical Applicability and Cost Analysis for Microwave Based Regenerating Permeable Reactive Barriers (MW-PRBs) Operating in Cs-Contaminated Groundwater Treatment. J. Environ. Manag. 2020, 260, 110064. [CrossRef]

14. Velimirovic, M.; Bianco, C.; Ferrantello, N.; Tosco, T.; Casasso, A.; Sethi, R.; Schmid, D.; Wagner, S.; Miyajima, K.; Klaas, N.; et al. A Large-Scale 3D Study on Transport of Humic Acid-Coated Goethite Nanoparticles for Aquifer Remediation. Water 2020, 12, 1207. [CrossRef]

15. Capodici, M.; Avona, A.; Laudicina, V.A.; Viviani, G. Biological Groundwater Denitrification Systems: Lab-Scale Trials Aimed at Nitrous Oxide Production and Emission Assessment. Sci. Total Environ. 2018, 630, 462-468. [CrossRef] [PubMed]

16. Sprocati, R.; Gallo, A.; Sethi, R.; Rolle, M. Electrokinetic Delivery of Reactants: Pore Water Chemistry Controls Transport, Mixing, and Degradation. Environ. Sci. Technol. 2021, 55, 719-729. [CrossRef]

17. Reddy, K.R.; Cameselle, C. Electrochemical Remediation Technologies for Polluted Soils, Sediments and Groundwater; John Wiley \& Sons, Inc.: Hoboken, NJ, USA, 2009; ISBN 978-0-470-52365-0.

18. Rada, E.C.; Andreottola, G.; Istrate, I.A.; Viotti, P.; Conti, F.; Magaril, E.R. Remediation of Soil Polluted by Organic Compounds Through Chemical Oxidation and Phytoremediation Combined with DCT. IJERPH 2019, 16, 3179. [CrossRef]

19. CRC CARE A Technical Guide for Demonstrating Monitored Natural Attenuation of Petroleum Hydrocarbons in Groundwater. Available online: https:/ / bit.ly/3loAaVG (accessed on 17 February 2021).

20. Suthersan, S.S.; Horst, J.; Schnobrich, M.; Welty, N.; McDonough, J. Remediation Engineering: Design Concepts; CRC Press: Boca Raton, FL, USA, 2016; ISBN 1-4987-7336-2. 
21. Beames, A.; Broekx, S.; Lookman, R.; Touchant, K.; Seuntjens, P. Sustainability Appraisal Tools for Soil and Groundwater Remediation: How Is the Choice of Remediation Alternative Influenced by Different Sets of Sustainability Indicators and Tool Structures? Sci. Total Environ. 2014, 470-471, 954-966. [CrossRef]

22. Song, B.; Zeng, G.; Gong, J.; Liang, J.; Xu, P.; Liu, Z.; Zhang, Y.; Zhang, C.; Cheng, M.; Liu, Y.; et al. Evaluation Methods for Assessing Effectiveness of in Situ Remediation of Soil and Sediment Contaminated with Organic Pollutants and Heavy Metals. Environ. Int. 2017, 105, 43-55. [CrossRef]

23. Canevaro, E.; Ingaramo, R.; Lami, I.M.; Morena, M.; Robiglio, M.; Saponaro, S.; Sezenna, E. Strategies for the Sustainable Reindustrialization of Brownfields. Iop Conf. Ser. Earth Environ. Sci. 2019, 296, 012010. [CrossRef]

24. Palma, V.; Accorsi, F.; Casasso, A.; Bianco, C.; Cutrì, S.; Robiglio, M.; Tosco, T. AdRem: An Integrated Approach for Adaptive Remediation. Sustainability 2020, 13, 28. [CrossRef]

25. Casasso, A.; Tosco, T.; Bianco, C.; Bucci, A.; Sethi, R. How Can We Make Pump and Treat Systems More Energetically Sustainable? Water 2019, 12, 67. [CrossRef]

26. Fetter, C.W.; Boving, T.; Kreamer, D. Contaminant Hydrogeology; Waveland Press: Long Grove, IL, USA, 2017; ISBN 1-4786-3650-5.

27. Antelmi, M.; Renoldi, F.; Alberti, L. Analytical and Numerical Methods for a Preliminary Assessment of the Remediation Time of Pump and Treat Systems. Water 2020, 12, 2850. [CrossRef]

28. Suthersan, S.; Killenbeck, E.; Potter, S.; Divine, C.; LeFrancois, M. Resurgence of Pump and Treat Solutions: Directed Groundwater Recirculation. Groundw. Monit Remediat. 2015, 35, 23-29. [CrossRef]

29. Pedretti, D.; Masetti, M.; Beretta, G.P. Stochastic Analysis of the Efficiency of Coupled Hydraulic-Physical Barriers to Contain Solute Plumes in Highly Heterogeneous Aquifers. J. Hydrol. 2017, 553, 805-815. [CrossRef]

30. Truex, M.; Johnson, C.; Macbeth, T.; Becker, D.; Lynch, K.; Giaudrone, D.; Frantz, A.; Lee, H. Performance Assessment of Pump-and-Treat Systems. Groundw. Monit Remediat. 2017, 37, 28-44. [CrossRef]

31. Bortone, I.; Erto, A.; Nardo, A.D.; Santonastaso, G.F.; Chianese, S.; Musmarra, D. Pump-and-Treat Configurations with Vertical and Horizontal Wells to Remediate an Aquifer Contaminated by Hexavalent Chromium. J. Contam. Hydrol. 2020, $235,103725$. [CrossRef]

32. Fiedler, L.; Pachon, C. Recent Trends in the Selection of Remedies for Groundwater, Soil, and Sediment at Superfund Sites. Groundw. Monit. Remediat. 2018, 38, 13-18. [CrossRef]

33. Tatti, F.; Petrangeli Papini, M.; Torretta, V.; Mancini, G.; Boni, M.R.; Viotti, P. Experimental and Numerical Evaluation of Groundwater Circulation Wells as a Remediation Technology for Persistent, Low Permeability Contaminant Source Zones. J. Contam. Hydrol. 2019, 222, 89-100. [CrossRef] [PubMed]

34. USEPA. Cost Analyses for Selected Groundwater Cleanup Projects: Pump and Treat Systems and Permeable Reactive Barriers. Available online: https:/ / bit.ly/2NEmEjO (accessed on 17 February 2021).

35. USEPA. Groundwater Pump and Treat Systems: Summary of Selected Cost and Performance Information at Superfund-Financed Sites. Available online: http:/ / bit.ly /2PEiXJX (accessed on 12 December 2018).

36. USEPA. Cost-Effective Design of Pump and Treat Systems. Available online: https://clu-in.org/download/remed/hyopt/ factsheets/cost-effective_design.pdf (accessed on 17 September 2019).

37. Majone, M. Sustainable Technologies for Groundwater Remediation. Available online: http:/ /bit.ly/Majone2009 (accessed on 18 November 2020).

38. Chien, C.C.; Inyang, H.I.; Everett, L.G. Barrier Systems for Environmental Contaminant Containment and Treatment; CRC/Taylor \& Francis: Boca Raton, FL, USA, 2006; ISBN 978-1-4200-3731-9.

39. Bayer, P.; Finkel, M.; Teutsch, G. Combining Pump-and-Treat and Physical Barriers for Contaminant Plume Control. Ground Water 2004, 42, 856-867. [CrossRef] [PubMed]

40. Bayer, P.; Finkel, M.; Teutsch, G. Cost-Optimal Contaminant Plume Management with a Combination of Pump-and-Treat and Physical Barrier Systems. Groundw. Monit. Remediat. 2005, 25, 96-106. [CrossRef]

41. Bayer, P.; Finkel, M. Conventional and Combined Pump-and-Treat Systems under Nonuniform Background Flow. Ground Water 2006, 44, 234-243. [CrossRef]

42. Manassero, M.; Schackelford, C.D. The Role of Diffusion in Contaminant Migration through Soil Barriers. Riv. Ital. Geotec. 1994, 1, 5-23.

43. Javandel, I.; Tsang, C.-F. Capture-Zone Type Curves: A Tool for Aquifer Cleanup. Ground Water 1986, 24, 616-625. [CrossRef]

44. USGS. MODFLOW and Related Programs. Available online: https:/ / bit.ly/USGS_MODFLOW (accessed on 22 November 2020).

45. Diersch, H.J.G. FEFLOW. Finite Element Modeling of Flow, Mass and Heat Transport in Porous and Fractured Media; Springer: Berlin/Heidelberg, Germany, 2014; ISBN 978-3-642-38738-8.

46. USEPA. A Systematic Approach for Evaluation of Capture Zones at Pump and Treat Systems. Available online: https://bit.ly/ 3wQCIRK (accessed on 12 April 2021).

47. Tosco, T.; Sethi, R. Comparison between Backward Probability and Particle Tracking Methods for the Delineation of Well Head Protection Areas. Env. Fluid Mech 2010, 10, 77-90. [CrossRef]

48. Langevin, C.D.; Hughes, J.D.; Banta, E.; Provost, A.; Niswonger, R.; Panday, S. MODFLOW 6, the U.S. Geological Survey Modular Hydrologic Model. Available online: https:/ / water.usgs.gov/ogw/modflow/MODFLOW.html (accessed on 5 February 2021).

49. ITRC. Use and Measurement of Mass Flux and Mass Discharge. Available online: https://bit.ly/3wNUogW (accessed on 13 April 2021). 
50. Walker, T.R.; MacAskill, N.D.; Thalheimer, A.H.; Zhao, L. Contaminant Mass Flux and Forensic Assessment of Polycyclic Aromatic Hydrocarbons: Tools to Inform Remediation Decision Making at a Contaminated Site in Canada. Remediation 2017, 27, 9-17. [CrossRef]

51. Bayer, P.; Finkel, M. Life Cycle Assessment of Active and Passive Groundwater Remediation Technologies. J. Contam. Hydrol. 2006, 83, 171-199. [CrossRef]

52. Cadotte, M.; Deschênes, L.; Samson, R. Selection of a Remediation Scenario for a Diesel-Contaminated Site Using LCA. Int. J. Life Cycle Assess. 2007, 12, 239. [CrossRef]

53. Higgins, M.R.; Olson, T.M. Life-Cycle Case Study Comparison of Permeable Reactive Barrier versus Pump-and-Treat Remediation. Environ. Sci. Technol. 2009, 43, 9432-9438. [CrossRef] [PubMed]

54. Hou, D.; Al-Tabbaa, A.; Luo, J. Assessing Effects of Site Characteristics on Remediation Secondary Life Cycle Impact with a Generalised Framework. J. Environ. Plan. Manag. 2014, 57, 1083-1100. [CrossRef]

55. Evans, J.C.; Ruffing, D.G.; Reddy, K.R.; Kumar, G.; Chetri, J.K. Sustainability of Vertical Barriers for Environmental Containment. In Sustainable Environmental Geotechnics; Reddy, K.R., Agnihotri, A.K., Yukselen-Aksoy, Y., Dubey, B.K., Bansal, A., Eds.; Lecture Notes in Civil Engineering; Springer International Publishing: Cham, Switzerland, 2020; Volume 89, pp. 271-283. ISBN 978-3-03051349-8.

56. ANIPA. Price List for Water Well Drilling Activities. Available online: https:/ / bit.ly/37GOfrR (accessed on 23 February 2021).

57. Bortone, I.; Chianese, S.; Di Nardo, A.; Di Natale, M.; Erto, A.; Musmarra, D. A Comparison between Pump Treat Technique and Permeable Reactive Barriers for the Remediation of Groundwater Contaminated by Chlorinated Organic Compounds. Chem. Eng. Trans. 2013, 32, 31-36. [CrossRef]

58. Nagheli, S.; Samani, N.; Barry, D.A. Capture Zone Models of a Multi-Well System in Aquifers Bounded with Regular and Irregular Inflow Boundaries. J. Hydrol. X 2020, 7, 100053. [CrossRef]

59. Conroy, J.P.; Elmore, A.C.; Crow, M. Capture Zone Comparison for Photovoltaic Microgrid-Powered Pump and Treat Remediation. J. Hazard. Toxic Radioact. Waste 2014, 18, 04014009. [CrossRef]

60. Cortes Di Lena, Y.; Elmore, A.C. General Method for Predicting Capture Zone Widths for PV-Powered Pump-and-Treat Systems Using PVWATTS and Basic Hydrogeologic Data. J. Environ. Eng. 2015, 141, 04015041. [CrossRef]

61. Guo, Z.; Brusseau, M.L.; Fogg, G.E. Determining the Long-Term Operational Performance of Pump and Treat and the Possibility of Closure for a Large TCE Plume. J. Hazard. Mater. 2019, 365, 796-803. [CrossRef] [PubMed] 